\title{
Sustainable development education in public administration graduate programs: the cases of Pamukkale and Niğde Ömer Halisdemir Universities
}

\author{
Onur Kulaç ${ }^{1,2 *}$, Hava Tahtalıoğlu3 \\ 1 University of Southern California, Sol Price School of Public Policy (Visiting Research Scholar), \\ USA, e-mail: ok_625@usc.edu; \\ 2 Pamukkale University Faculty of Economics and Administrative Sciences Department of Political \\ Science and Public Administration, Turkey, e-mail: onurkulac@yahoo.com \\ 3 Niğde Ömer Halisdemir University Faculty of Economics and Administrative Sciences \\ Department of Political Science and Public Administration, Turkey, e-mail: \\ htahtalioglu@gmail.com \\ * Correspondence: ok_625@usc.edu / onurkulac@yahoo.com
}

Keywords: sustainable development, public administration education, Turkey

\begin{abstract}
Adaptation of environmental literacy awareness to the education system and reflection of interest and attitude towards the environment in behavior is a critical element in order to ensure sustainable development. Turkey's interest in the environment and sustainable development began to increase at the end of the 20th century. Unfortunately, the reflection of this interest in the education system has not been at the desired level. The foremost aim of the study is to measure the level of consciousness and awareness about sustainable development of the students who are in the master's programs of the department of public administration. As a sample, students studying in the relevant field between 2018-2020 at Pamukkale University and Niğde Ömer Halisdemir University Social Sciences Institute were selected. In this study, where the qualitative method was preferred, the data of 20 students who provided feedback to the 11-expression interview form were analyzed using the word cloud method. It was concluded that the participants began to examine the relationship between the environmental factor and sustainable development, understood the importance of sustainable development for future generations, but could not adequately reflect the consciousness and awareness they had achieved in their behavior.
\end{abstract}

\section{Introduction}

The 21st century is witnessing surprising developments in many respects. Globalization, migration, rapid population growth, environmental pollution, and finally, the COVID-19 pandemic, which has affected the whole world, bring various problems. Therefore, it is of functional importance that the states' strategies, plans, and programs against the problems that directly affect society are sustainable. In addition, long-term policies made in different areas are also necessary for sustainability. It is stated that the concept of sustainability has a crucial place in overcoming the ecological crisis like many problems in the world (Aydoğan-Boschele, 2020: 12). For this reason, it can be a promising step to include concepts such as sustainability and sustainable development, especially in university curricula, or to carry out activities related to it. Ali-Khan (1990) also emphasized the relationship between professional environmental literacy, personal environmental literacy, and environmental competence. 
The discipline of public administration has undergone significant changes and transformations in the last 20 years, as a result of which there have also been updates in course content, teaching techniques and academic interests (Yıldız \& Babaoğlu, 2018). The discipline of public administration gives importance to fundamental issues such as government functions and policy implementation processes. In addition, future public sector administrators receive both professional and theoretical training through public administration. In this context, the field of public administration, which has an interdisciplinary feature, benefits from different disciplines as theory, practice, and method (Van der Waldt, 2014: 80-81, 186). Public officials who have received training in public administration are expected to have knowledge of administration systems functions, policies, and processes. However, educational content standards are not fully defined (Van Dijk \& Thornhill, 2011: 7-16). The big questions about public administration education are looking for answers. These questions are often discussions of the method of delivering education and the curriculum (Denhardt, 2001).

Researchers have also conducted comparative country analyses of the presentation of public administration education and curriculum (see Hajnal, 2003; Onder \& Brower, 2013; Purón-Cid, 2019; Rauhaus \& Sakiev, 2018; Wessels, 2010; Yıldız et al., 2011; Yıldız et al., 2016; ). In this way, comprehensive assessments of public administration education and curriculum in different countries and even policy transfers are involved. In addition, there are comparative studies within the framework of Master of Public Administration and Master of Public Policy (Hur \& Hackbart, 2009; Infeld \& Adams, 2011; Morçöl et al., 2020) as well as functional discussions regarding the fundamental dynamics of MPA education (such as problem-solving, decision making, policy making, governance) (Haupt et al., 2017; Yıldız et al., 2017). In this context, when the main themes of the Teaching Public Administration Journal, which is one of the leading journals in the field, are scrutinized, it is seen that the prominent themes are listed as teaching methods and pedagogy, public service training, decentralization and devolution, ethics, what is public administration? (Fenwick, 2017). Rangarajan \& Joshi (2019) emphasize that no study questions the status of sustainability education in public administration education. In this context, based on the findings and the determinations of Rangarajan \& Joshi (2019), this study aims to fill the void in the relevant literature. To this end, this study aims to measure the level of consciousness and awareness of sustainable development of students studying in the master's program in public administration.

\section{Methodology of the Study}

In this study, it is aimed to measure the level of awareness of graduate students about sustainable development. One of the main factors affecting the level of awareness about sustainable development is that individuals have taken courses on the environment in their education periods. Therefore, the fact that environmental education is given in the Department of Political Science and Public Administration or Public Administration (especially in the undergraduate level departments in this field) in Turkey gives the impression that students studying for a master's degree in this field are suitable for study.

The data obtained using qualitative research methods were visualized using word clouds in the study. Word cloud is a method that provides the presentation of a composition based on the frequency of use in the resulting data and the visual created in this context in studies. Although it was originally designed for pleasure, it is almost a functional method for analyzing textual data (Feinberg, 2010: 37). These data, which are detected and visualized in different dimensions according to the frequency level, are important in order to inform readers quickly (Fronza et al., 2013: 58). This technique first appeared online in the 1990s under the name of tag clouds. Subsequently, a site 
called Wordle simplifies the creation of word clouds; It has enabled more usage and visualization (Harris, 2011).

In the study, firstly, the data obtained through semi-structured interview questions were grouped. Then, the data were analyzed with the MAXQDA 2020 program, and the frequency levels of the words were determined. Furthermore, the WordArt program was used for visual reflection. The stages expressed in the study of Fronza et al. (2013: 59) were considered in this study.

\subsection{Sampling}

As of 2021, there are 129 State Universities in Turkey (YÖK, 2021). In 93 state universities, undergraduate education in 96 departments under the name of Political Science and Public Administration or Public Administration is offered (ÖSYM, 2020). In 81 of 93 State Universities, graduate education with the same names as the department is provided within the scope of the Graduate Education Institute / Institute of Social Sciences. State universities established in 1992, which were found to have at least one in each region of Turkey and which are assumed to have the same history of institutionalization, were selected as the first sample. In this context, first of all, the names and contents of the courses taught at the graduate level in the relevant departments of Universities established in 1992 in Turkey were examined. Subsequently, the sample in which the interview method will be used need to be selected. The convenience sampling method, which is one of the non-random sampling methods, was used in the sample selection. With this method, students were selected who studied Master of Political Science and Public Administration or Public Administration (Public Administration and Urban Studies) between 2018-2020 at Pamukkale and Niğde Ömer Halisdemir Universities, which were established in 1992.

\subsection{Data Collection Tool and Data Analysis Process}

A qualitative data collection method was used in the study. First, researchers created a semi-structured open-ended interview form to measure demographic information and scrutinize the topic in depth. This interview form was sent to three academics who have researches in the relevant field to get expert opinions. Then, in line with the views of the academics, the interview form was finalized with six statements to measure the demographic information that was thought to support the main subject of the study and 11 statements to enlighten the relevant subject.

In the study, two separate data were analyzed. The first of these is the course titles and contents taught in the relevant departments of universities established in 1992 in Turkey. Within the context of these data obtained through document analysis, it is aimed to measure the frequency of referring to the expressions "sustainable development, development, environment and environmental education" in the relevant subdepartments. The second method used in the study, the semi-structured open-ended interview form, which was presented to the graduate students enrolled in the relevant graduate programs of two selected universities and they were asked to respond on a voluntary basis. In this context, feedback was received from a total of 20 students, and content analysis ${ }^{1}$ was applied to the obtained data. The qualitative data analysis process and the model preferred in the study can be illustrated as follows (Gürbüz \& Şahin, 2016):

\footnotetext{
${ }^{1}$ Content analysis is the gathering and arrangement of data within the framework of specific concepts and themes (Gürbuz \& Şahin, 2016: 405).
} 


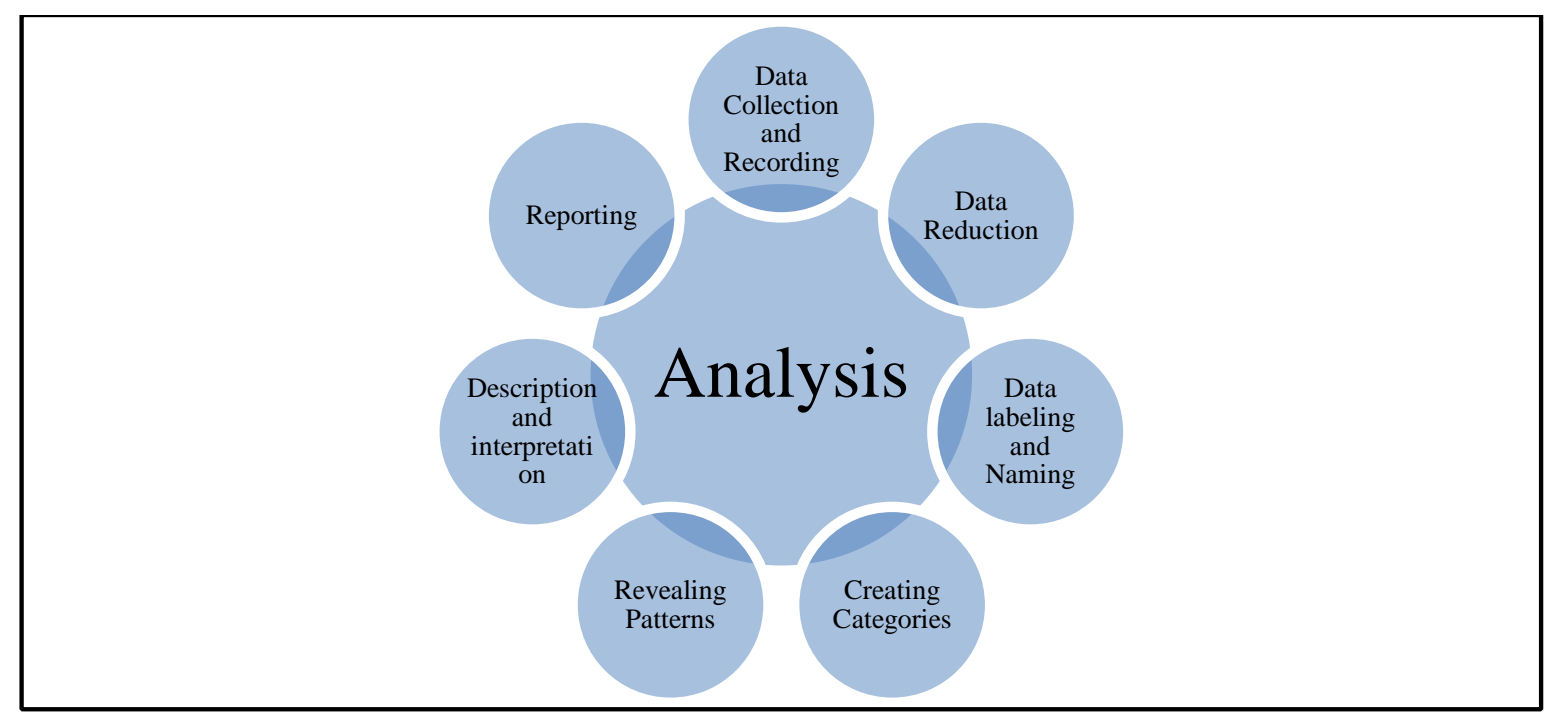

Figure 1. The Model of the Research

\section{Findings}

In this part of the study, firstly, the findings obtained by examining the courses and their contents in the relevant departments in universities established in Turkey in 1992 will be reflected. The data set obtained from the students who received graduate education (Master's Level) in the relevant field between 2018-2020 at the universities selected as samples will be analyzed in the further stage.

\subsection{Environmental Education at the Graduate Level in Universities Established in 1992}

The study universe is 81 departments providing graduate education in Political Science and Public Administration or Public Administration. Due to the fact that the number is quite large and the limitations of the study, universities established in 1992 and providing education in the relevant department are compiled in Table 1.

Table 1. Universities Established in 1992 and Providing Postgraduate Education in the Relevant Department

\begin{tabular}{|c|c|c|c|c|c|}
\hline University Name & Master & PhD & University name & Master & PhD \\
\hline Afyon Kocatepe University & $x$ & $x$ & Kocaeli University & $x$ & $x$ \\
\hline Aydın Adnan Menderes University & $x$ & - & Kütahya Dumlupınar University & $x$ & $x$ \\
\hline Balıkesir University & $x$ & - & Manisa Celal Bayar University & $x$ & - \\
\hline Bolu Abant İzzet Baysal University & $x$ & $x$ & Mersin University & $x$ & $x$ \\
\hline Çanakkale Onsekiz Mart University & $x$ & $x$ & Muğla Sıtkı Koçman University & $x$ & $x$ \\
\hline Harran University & $x$ & $x$ & Niğde Ömer Halisdemir University & $x$ & - \\
\hline Hatay Mustafa Kemal University & $x$ & $x$ & Pamukkale University & $x$ & $x$ \\
\hline Kafkas University & $x$ & - & Sakarya University & $\mathrm{x}$ & $x$ \\
\hline $\begin{array}{l}\text { Kahramanmaraş Sütçü İmam } \\
\text { University }\end{array}$ & $x$ & $x$ & Süleyman Demirel University & $x$ & $x$ \\
\hline \multirow[t]{2}{*}{ Kırıkkale University } & $x$ & $x$ & Tokat Gaziosmanpaşa University & $x$ & - \\
\hline & & & Zonguldak Bülent Ecevit University & $x$ & - \\
\hline
\end{tabular}


Total: 21 Universities

Only two of the 23 public universities established in 1992 in Turkey do not have master's and/or doctoral studies in the Departments of Political Science and Public Administration or Public Administration. Seven of the 21 universities offer only a master's program, and 14 universities offer both a master's and a doctorate program.

In the study, firstly, the names and contents of the courses in the relevant subdepartments are examined on the websites of 21 universities established in 1992 in Turkey. In this context, there is no information about the courses on the website of only one of the 21 universities. In the other university, where information is available on their websites, the words such as sustainable development, development, environment, and environmental education were searched first in the course titles and then in the course contents. In only one of these, no lessons contained related expressions. In the graduate programs in 19 departments, courses including issues related to the politics, philosophy, security, law and management of national and/or global environmental problems are included. While only one of the 50 courses studied in the scope of the study has the word "sustainable" in its name, the content of six courses with this course touched on sustainable development and/or environmental issues. In three of the other courses, the word "development" is found either in the course names or in their content.

\subsection{Sustainable Development Education Findings in the Sub-Department of Public Administration}

In the study, the demographic characteristics of the participants were examined, and various findings were reached as a result of the content analysis of the data obtained by interview forms.

\subsubsection{Demographic Findings}

Seven of the participants in the study are women, and 13 of them are men. The average age of the participants is 27. It is seen that 19 of the participants received political science and public administration or public administration education in their undergraduate level education background, while one of them received medicine and the other received classroom teacher education. One of the participants is a graduate of the department of political science and international relations at the undergraduate level. When the graduate stages are examined, it is seen that three of the participants are in the thesis stage, and the others are in the pre-thesis stage. It was observed that 12 participants included in the study had work experience, and seven of them had administrative tasks, while eight of them did not have any work experience.

\subsubsection{Findings on Sustainable Development Awareness}

The first question posed to the participants in the semi-structured interview form aims to measure their sustainability development awareness. In line with the findings obtained, the concepts of "future" and "future generations/generations", which are frequently expressed in the definitions of sustainable development, come to the fore. While thirteen participants expressed this concept, the other participants focused on the effective use of natural resources by drawing attention to the national and international requirements of the sustainable development process. These participants also stated that the environment would be protected with the effective use of resources in the development process. The word cloud consisting of the answers of the participants is seen in Figure 2. 


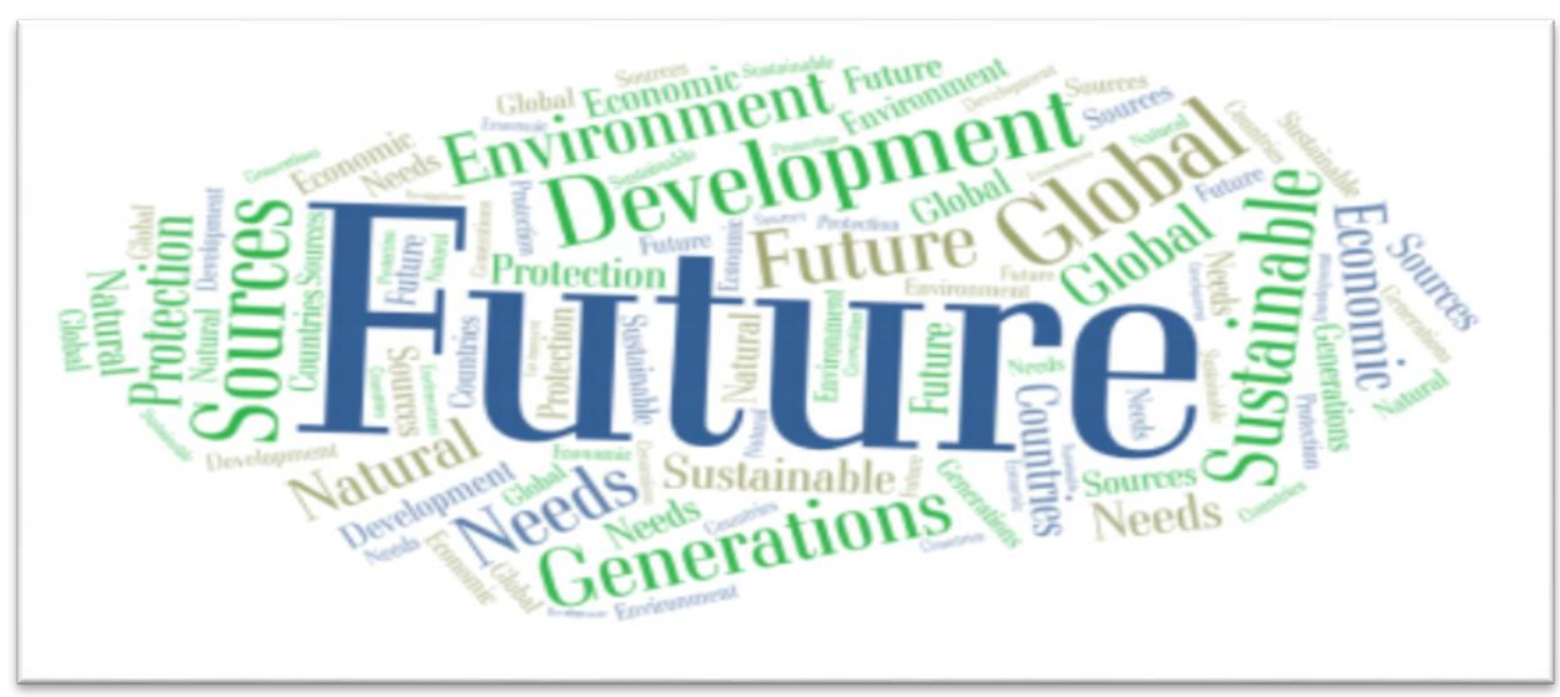

Figure 2. Sustainable Development Awareness

\subsubsection{Level of Environmental Education to Raise Awareness of Sustainable Development}

Participants were asked in the 2nd and 3rd statements whether they have taken environmental-related courses during their undergraduate and graduate education processes. Nine participants stated that they did not have any course related to the environment at the undergraduate level. Also, ten of the participants stated that they did not take a course in the field of the environment at the master's level. Other participants who stated that they had taken lessons about the environment indicated that the content of the courses for at least one week was carried out by addressing the relevant topic to raise awareness of sustainable development. Moreover, one of the participants stated that he participated in activities related to the environmental damage of oils used in the kitchen as part of the undergraduate course. Another participant declared that they touched on the concept of sustainable development in the local government Course at the master's level. Participants were asked whether lectures related to environmental education were sufficient in terms of sustainable development awareness. Thirteen participants stated that these graduate courses were insufficient to create awareness of sustainable development, while two participants indicated that they were sufficient. One participant stated that there were partially sufficient, while the other three participants stated that they could not express their opinion because they did not take any lectures. Another participant stated that he did not take lessons related to environmental ducation, but based on his observations, he thought that it was not sufficient. Two of the participants actually stated that awareness would be better created by reflecting on this subject in practice given in theory. Somuncu-Demir (2011: 17) also stated that practical implementation of environmental education could positively affect the development of attitudes, awareness, and behavior phenomena related to environmental understanding.

In line with the answers given to the 5th statement, in which the participants were asked for their opinions on how to provide sustainable development training to transform awareness into consciousness, there is a prevalent opinion that the lessons are important in order to create awareness. In this context, the suggestions stand out as environmental lessons, local administration lessons and lessons to be formed under the name of sustainable development. In the transformation of awareness into consciousness, it has been stated that importance should be given to the practices after the theoretical courses, which are taken into account in the international criteria together with the 
national criteria. The word cloud consisting of the answers of the participants can be followed in Figure 3.

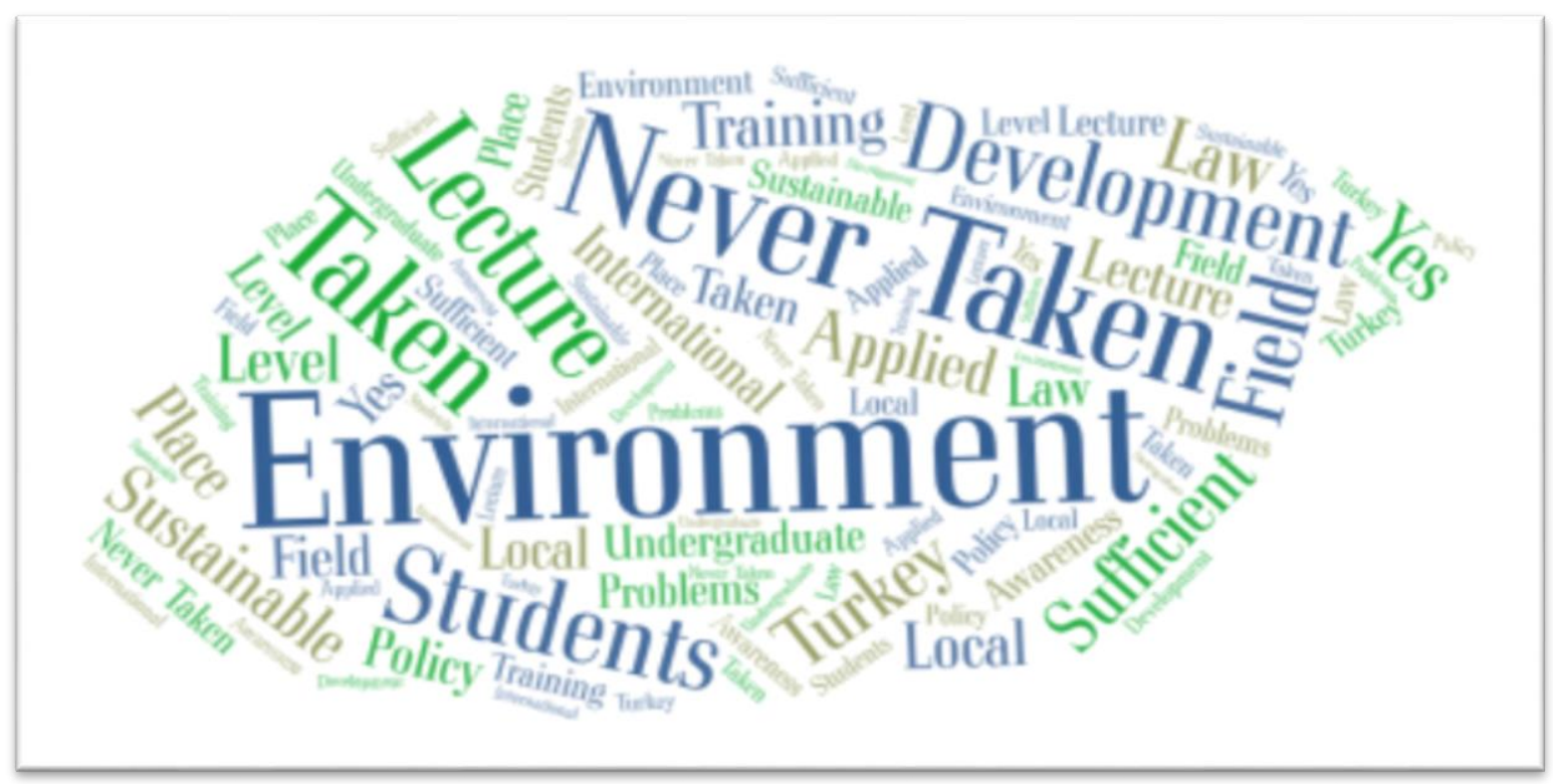

Figure 3. Environmental Education to Raise Awareness of Sustainable Development

\subsubsection{Interest in Sustainable Development}

Questions 6, 7 and 9 in the semi-structured interview form are designed to measure participants' interest in sustainable development. First, participants are asked whether they prefer the topic of sustainable development in their master's thesis. When the answers were examined, twelve participants stated that they did not think to work on this issue or decided on another subject. Moreover, seven participants declared that they are likely to work on sustainable development, and one participant has yet to decide.

In the 7th and 9th statements, the participant's interest in the sustainable development efforts in Turkey has been attempted to be determined. In this context, $50 \%$ of the participants stated that they had information about Turkey's 2030 Sustainable Development Strategy. The four participants who participated in the interview process stated that the efforts of politicians, educators and the scientific community on environmental education in the name of sustainable development had not drawn their attention. On the other hand, fourteen participants are of the opinion that the mentioned efforts and activities attract their attention, but these efforts are insufficient in Turkey. In the comments made by the participants towards politicians, scientists and educators, it is seen that there is a consensus that the efforts of the science world and educators are more realistic. However, participants also stated that politicians attach importance to the mentioned issue for political interests. The word cloud consisting of the answers of the participants can be seen in Figure 4. 


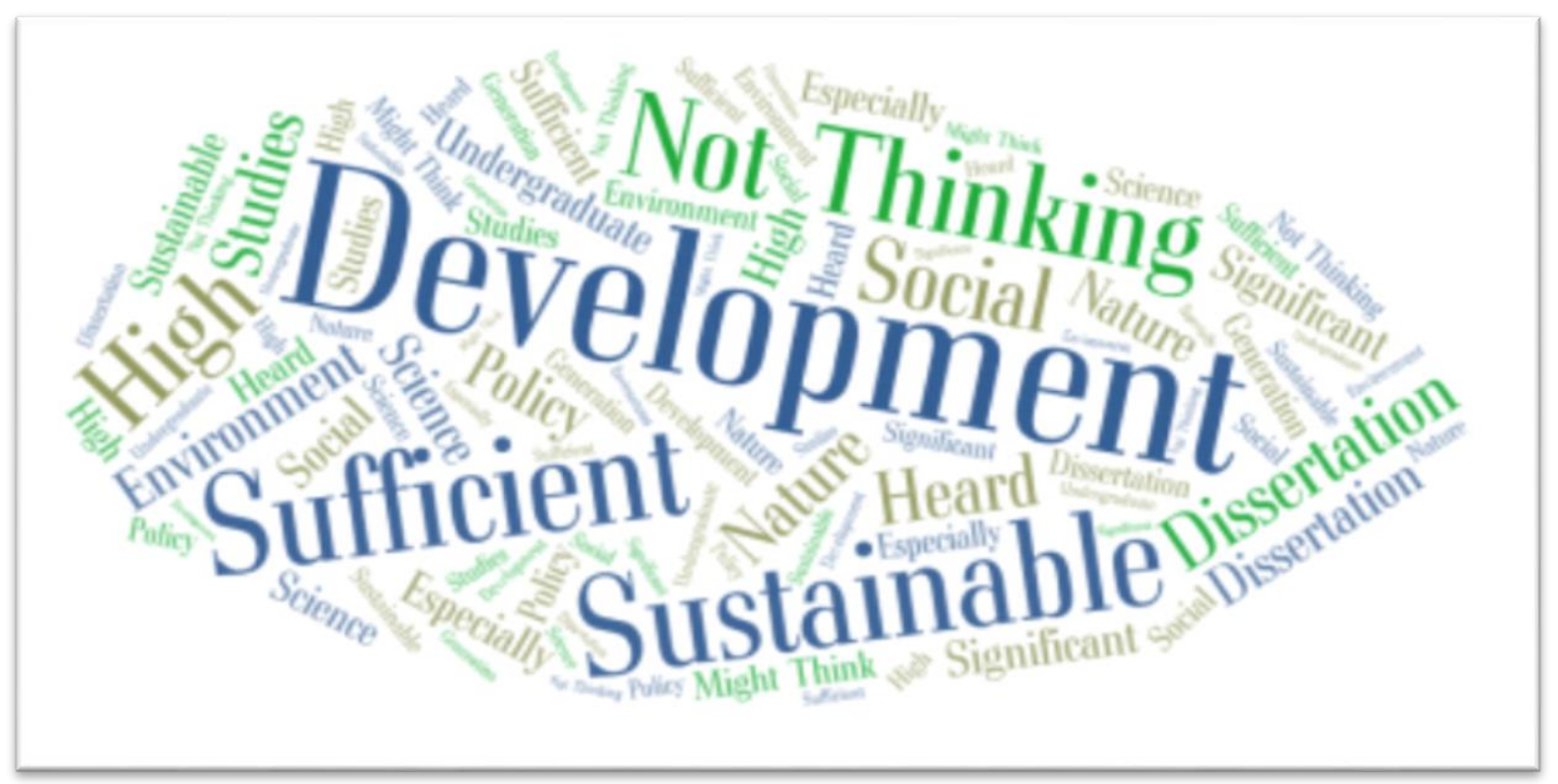

Figure 4. Interest in Sustainable Development

\subsubsection{The Role of Media in Sustainable Development}

Today, the media is of great importance in shaping the public policy process and public opinion. The role of the media in identifying problems in society and attracting the attention of decision-makers is valuable (Dye, 2013; Birkland, 2016). Since the sustainable development issue concerns the whole society, the activities of the media, which is a civil policy actor, are fundamental. Hence, aural and visual media have a critical place in the awareness of sustainable development (Alım, 2006: 605). On the other hand, the media is considered as one of the stakeholders in the sustainable management of resources and wastes (T.C. Cumhurbaşkanlığı Strateji ve Bütçe Başkanlığı, 2019: 182). However, the contribution of the media, which encourages consumption in today's societies, to sustainability should be questioned again (Aydogan - Boschele, 2020: 20-21).

The participants' responses to the 8th interview question to determine the sensitivity of the media on sustainable development in Turkey were evaluated in this section. In this context, eighteen of the participants are of the opinion that aural and visual media are not sensitive enough about sustainable development. On the other hand, one of the participants thinks that sensitivity is sufficient, while the other participant is of the opinion that if the awareness of sustainable development of the audio and visual media is sufficient, it will be possible to create public opinion in the society quickly and effectively. Generally, the participants touch on visual media, but they think that sensitivities in visual media cannot be achieved only with public spots. The word cloud consisting of the answers of the participants can be followed in Figure 5. 


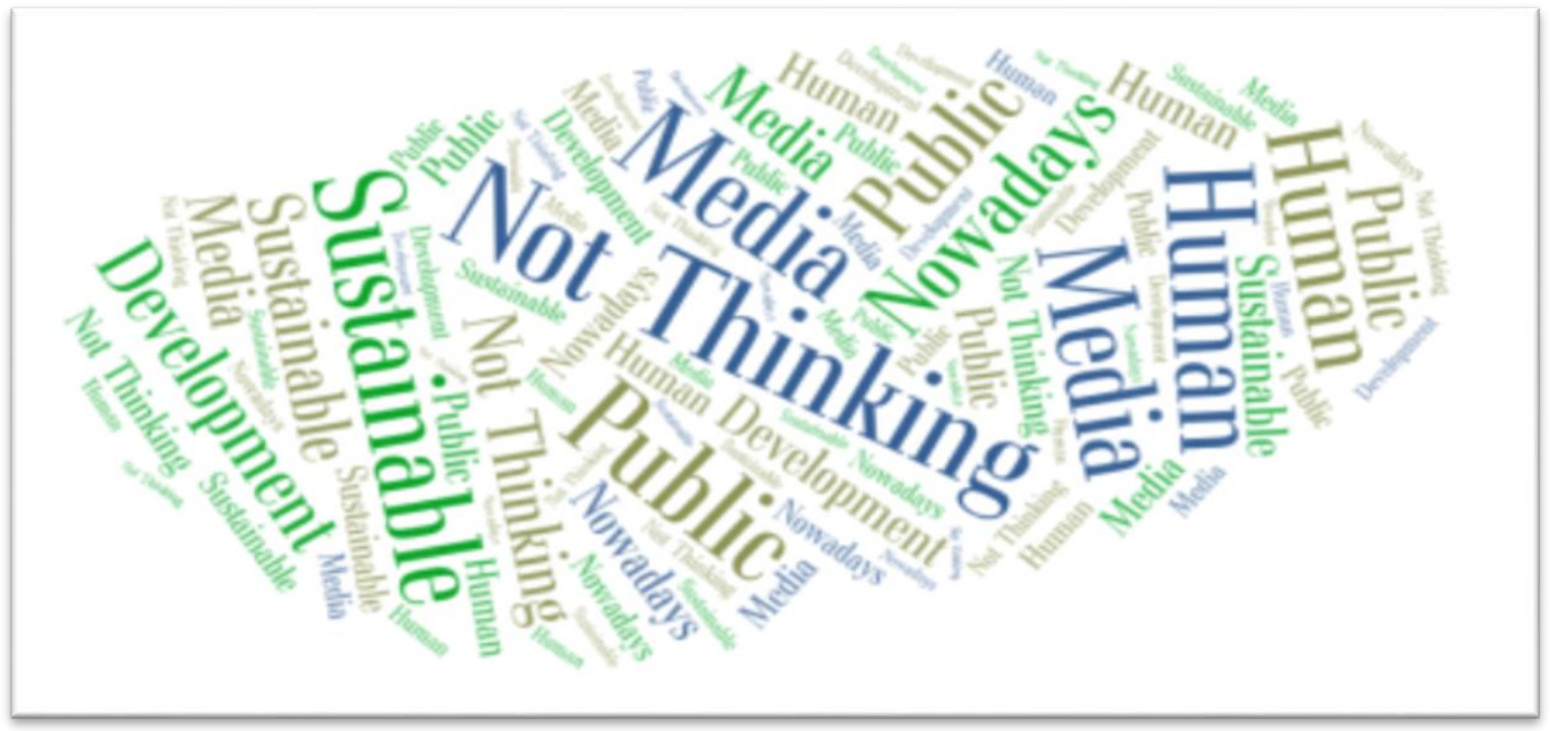

Figure 5. Role of Media in Sustainable Development

\subsubsection{Awareness Level Created by Sustainable Development Policies in Local Election Process}

In the last local elections held in Turkey, the 10th question was asked to the participants so as to see how the political actors behave in terms of sustainability and to determine the attitudes of the participants, who are voters, on this issue. $50 \%$ of the responses to this question show that candidates in local elections express that their policies on a sustainable environment have an impact on the votes. Seven participants in the study stated that such policies did not attract their attention in local elections, while another participant noted that local politicians did not have such policies.

The remaining two participants stated that local politicians prepared for the election to eliminate the failures in the local service sector with urban transformation policies in the name of environment and sustainability. The word cloud consisting of the answers of the participants can be seen in Figure 6.

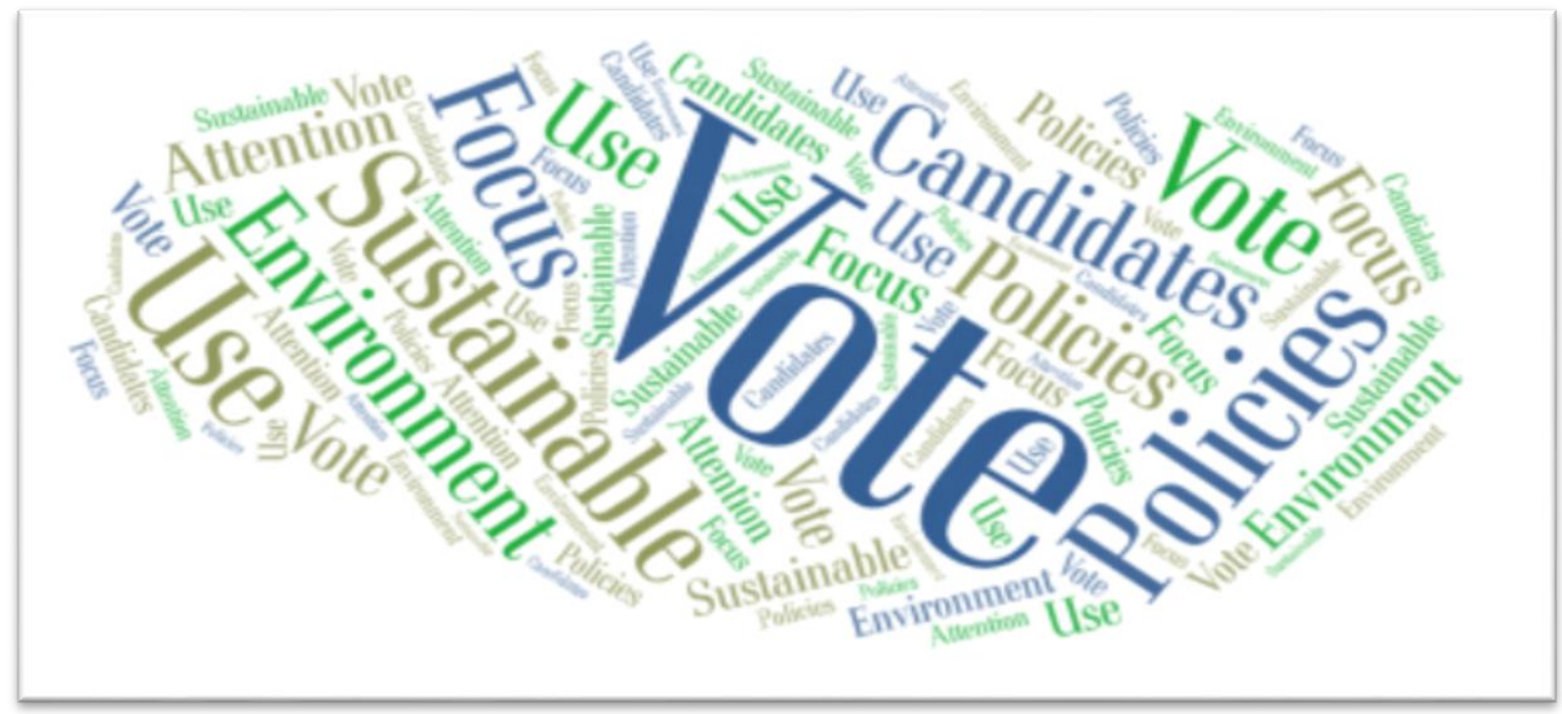

Figure 6. Sustainable Development Policies in Local Election Process

\subsubsection{General Summary of the Interviews}

As a result of the interviews conducted within the scope of the study, it is seen that the participants emphasized some points. These points can be summarized as follows: 
The need to be more sensitive about sustainable development due to the obligations to future generations, the importance of reflecting what is learned in theory into practice, raising the level of awareness and consciousness of sustainable development and the need for academia to focus more on sustainable development. Moreover, the points such as the need for the media to focus more on the mentioned topic, local governments, especially municipalities, need to be more sensitive to sustainable development and the importance of having announcements on boards in squares were overwhelmingly stated by the participants in the interview. Besides, the national and international dimension of the sustainable development issue is expressed by the participants, and the ideas that should be supported on legal grounds are declared. The word cloud consisting of the feedbacks of the participants can be followed in Figure 7.

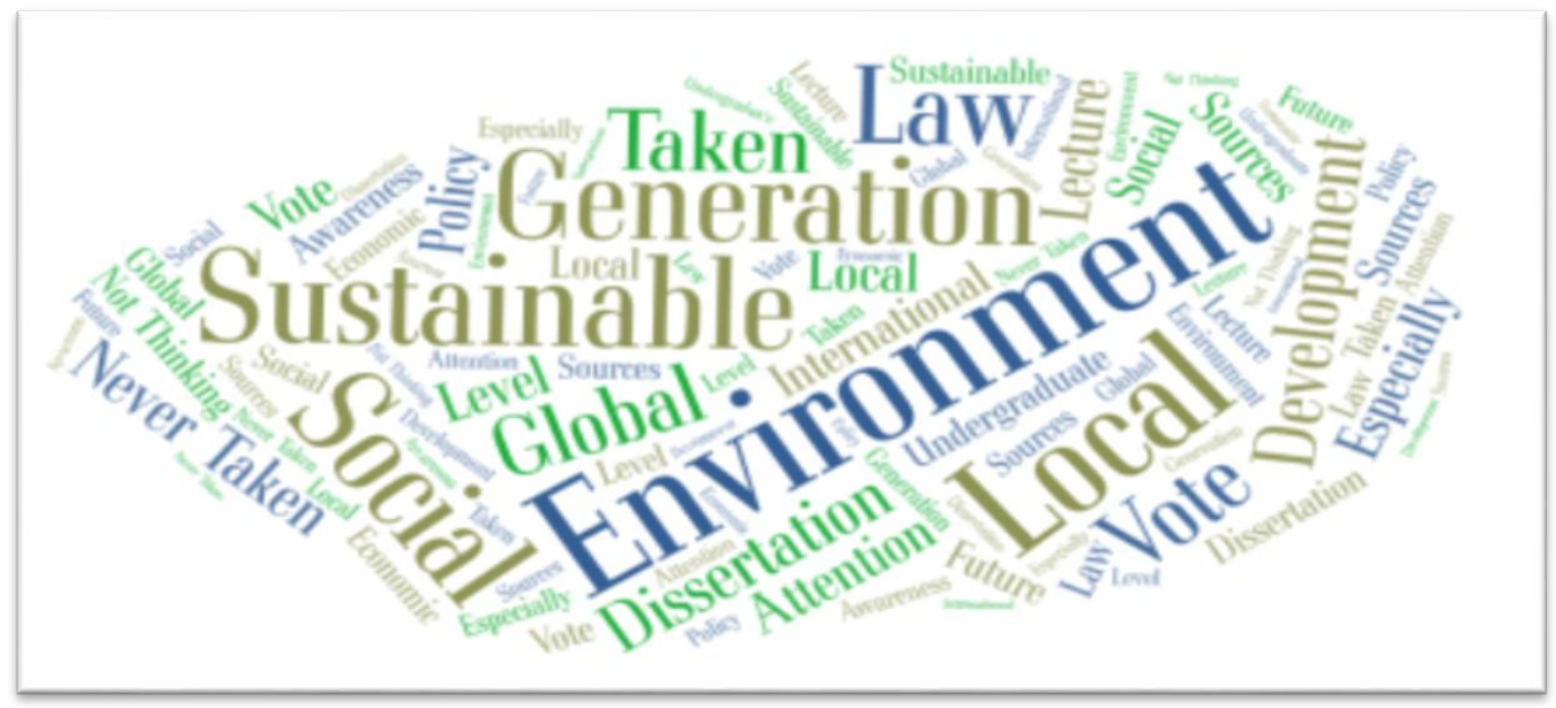

Figure 7. Summary of the Interviews

When the frequency intensities of the interviews conducted within the scope of the study are examined, essential findings are obtained, as can be followed in the Graph 1. The concepts of environment, sustainable development, future generations, and awareness were expressed 47,30, 14 and 9 times, respectively, by the students who participated in the interview. Consequently, it is seen that these statements come to the fore in the context of the concept of sustainable development in the graduate education of public administration.

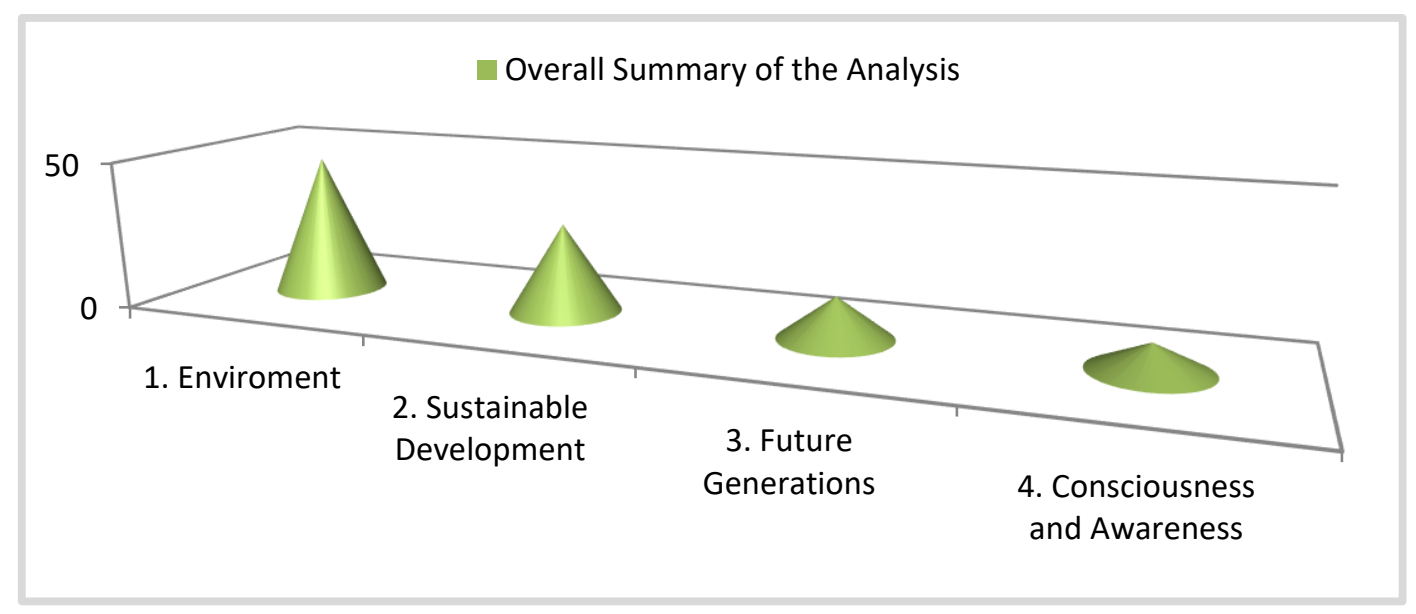

Graph 1. Overall Summary of the Analysis 


\section{Conclusion}

Education in political science and public administration is very functional and also necessary to provide human resources to serve in various levels of government in the country. Therefore, the significance of sustainable development for a better environment and future should be emphasized in political science and public administration education and more included in the curriculum. According to the outputs of the semi-structured interview directed to the participants in accordance with the purpose of the study, it was found that there is an awareness of sustainable development. Lectures on the environment and local governments in public administration departments have contributed significantly to the formation of the mentioned awareness. However, these pieces of training are not considered sufficient for sustainable development awareness to become a way of life. One participant stated that there were several activities about the environment in the course he took, and by distributing juniper saplings to the guests who came to his wedding, it raises the hope that the trainings reflected in the practice will also be reflected in the lifestyles of people.

Another response noted in line with the study's goal is that "such education can be obtained from family, intellectual competence, awareness and respect, rather than educational institutions". In this context, a need arises that providing education only at the undergraduate level is insufficient and that families should be conscious about this issue. To this end, environmental education should first be given to their children by parents (Sabo \& Gavrilă, 2011: 164) in an effort to support awareness in society regarding sustainable development.

Oğuz et al. (2011: 38) also stated in their study that the concept of environmental education has a multidisciplinary structure and includes many stakeholders consisting of students, teachers and educators, families, national and local governments, NGOs, etc. Sabo (2008) also put an emphasis on environmental education and training by analyzing the levels of various universities in Germany.

Unfortunately, the media, which plays a very active role in policy processes, does not care to a satisfactory degree about sustainable development Gürcüoğlu (2013) stated in her study that, as the participants noted, the activities of non-governmental organizations and the media about sustainable development are insufficient. It is promising for the future that various policies regarding the issue have been brought to the agenda in political life and that some of the participants cast their votes within the framework of these policies. The response of one of the participants to the 11th statement is noteworthy. The response is that" the study will raise awareness among graduate students but will not lead to change for politicians and administrators". This response has drawn attention to the fact that the administrative/political community neglects the studies done by the academic community in Turkey, as it is often stated. Therefore, it becomes necessary that such studies should be considered more by the relevant administrative and political units.

\section{References}

1. Ali-Khan, S. (1990). Greening Polytechnics: Working Document (Middlesex, Committee of Directors of Polytechnics).

2. Alım, M. (2006). Avrupa Birliği üyelik sürecinde Türkiye'de çevre ve ilköğretimde çevre eğitimi, Kastamonu Eğitim Dergisi, 14 (2), 599-616. Retrieved from https://dergipark.org.tr/tr/pub/kefdergi/issue/49104/626637.

3. Aydoğan-Boschele, F. (2020). Sürdürülebilirlik, tüketim ve medya, İnsan \& İnsan, 26, 11-23. DOI: https://doi.org/10.29224/insanveinsan.757873.

4. Birkland, T. A. (2016). An Introduction to the Policy Process: Theories, Concepts, and Models of Public Policy Making, 4th ed.; Routledge, New York, USD.

5. Denhardt, R. B. (2001). The big questions of public administration education, Public Administration Review, 61(5), 526-534, https://doi.org/10.1111/0033-3352.00125 
6. Dye, T. R. (2013). Understanding public policy, 14th ed.; Upper Saddle River, Pearson Education, New Jersey, USD.

7. Feinberg, J. (2010). Wordle. In Book Title, Eds.; J. Steele \& N. Iliinsky Beautiful visualization: Looking at Data through the eyes of experts, O'Reilly Media, Sebastapol, CA, pp.37-58.

8. Fenwick, J. (2017). Teaching public administration: Key themes 1996-2016, Teaching Public Administration, 36(1), 6-13, DOI: https://doi.org/10.1177/0144739417740180.

9. Fronza, I.; Janes, A.; Sillitti, A.; Succi, G. \& Trebeschi, S. (2013). Cooperation wordle using pre-attentive processing techniques. In 6th International Workshop on Cooperative and Human Aspects of Software Engineering (CHASE), 57-64, DOI: https://doi.org/10.1109/CHASE.2013.6614732.

10. Gürbüz, S. \& Şahin, F. (2016). Sosyal bilimlerde araştırma yöntemleri, 3. Baskı, Seçkin Yayınları, Ankara, Türkiye.

11. Gürcüoğlu, S. (2013). Türkiye'de çevre eğitiminde kamu örgütleri, sosyal toplum örgütleri ve medyanın rolü, Gazi Üniversitesi Íktisadi ve İdari Bilimler Fakültesi Dergisi, 15(3), 154-170, Retrieved from https://dergipark.org.tr/tr/pub/gaziuiibfd/issue/28312/300870.

12. Hajnal, G. (2003). Diversity and convergence: A quantitative analysis of European public administration education programs, Journal of Public Affairs Education, 9(4), 245-258, https://doi.org/10.1080/15236803.2003.12023597.

13. Harris, J. (2011). Word Clouds Considered Harmful, Nieman Journalism Lab. Available online: http://www.niemanlab.org/2011/10/word-clouds-considered-harmful// (accessed on 21.02.2021).

14. Hur, Y., \& Hackbart, M. (2009). MPA vs. MPP: A distinction without a difference?, Journal of Public Affairs Education, 15(4), 397-424, https://doi.org/10.1080/15236803.2 $\underline{009.12001569 .}$.

15. Haupt, B., Kapucu, N., \& Hu, Q. (2017). Core competencies in Master of Public Administration programs: Perspectives from local government managers, Journal of Public Affairs Education, 23(1), 611-624, DOI: https://doi.org/10.1080/15236803.2017.12002272.

16. Infeld, D. L., \& Adams, W. C. (2011). MPA and MPP students: twins, siblings, or distant cousins?, Journal of Public Affairs Education, 17(2), 277-303, https://doi.org/10.1080/15236803.2011.12001643.

17. Morçöl, G., Tantardini, M., Williams, A., \& Slagle, D. R. (2020). Master of Public Administration and Master of Public Policy degrees: Differences and similarities in the curricula and course contents, Teaching Public Administration, 38(3), 313-332, https://doi.org/10.1177/0144739420915758.

18. Oğuz, D., Çakcı, I., \& Kavas, S. (2011). Yükseköğretimde öğrencilerin çevre bilinci, Süleyman Demirel Üniversitesi Orman Fakültesi Dergisi, 12, 34-39, https://dergipark.org.tr/tr/download/article-file/195770.

19. Onder, M., \& Brower, R. S. (2013). Public administration theory, research, and teaching: How does Turkish public administration differ?, Journal of Public Affairs Education, 19(1), 117-139, https://doi.org/10.1080/15236803.2013.12001723.

20. ÖSYM (2020). Yükseköğretim kurumları sınavı (YKS) yükseköğretim programları ve kontenjanları kılavuzu. Available online: https:// dokuman.osym.gov.tr/pdfdokuman/2020/YKS/tkilavuz13082020.pdf (accessed on 27.01.2021).

21. Purón Cid, G. (2019). A comparative analysis of public affairs master's programs in the United States and the Latin American region, Journal of Public Affairs Education, 25(4), 495-523, https://doi.org/10.1080/15236803.2018.1489094.

22. Rangarajan, N., \& Joshi, S. (2019). Sustainability education in public administration and policy: A multi-method study of NASPAA accredited programs, Journal of Public Affairs Education, 25(3), 343-363, https://doi.org/10.1080/15236803.2018.1428045.

23. Rauhaus, B. M., \& Sakiev, A. (2018). A comparative analysis of public administration education in the United States and post-Soviet Central Asia, Journal of Public Affairs Education, 24(1), 27-42, https://doi.org/10.1080/15236803.2018.1429818. 
24. Sabo, H. M. (2008). Study of environmental education in the universities of Germany, Present Environment and Sustainable Development, 2, 89-100, http://pesd.ro/articole/nr.2/9.\%20Sabo_PESD_2008.pdf (accessed on 27.05.2021).

25. Sabo, H. M., \& Gavrilă, C. (2011). The impact of flooding and environmental education, Present Environment and Sustainable Development, 5(2), 159-166, http://pesd.ro/articole/nr.5/2/14.\%20Sabo.pdf (accessed on 27.05.2021).

26. Somuncu-Demir, N. (2011). Sürdürülebilir çevre eğitimi kapsamında gerçekleştirilen tarım uygulamalı bahçe temelli eğitim modelinin değerlendirilmesi, Gazi University Institute of Educational Sciences, Unpublished Master's Thesis, Ankara, Türkiye.

27. T.C. Cumhurbaşkanlığı Strateji ve Bütçe Başkanlığı (2019). Sürdürülebilir kalkınma amaçları değerlendirme raporu. Available online: https://sbb.gov.tr/wp-content/uploads/2020/03/ Surdurulebilir-Kalkinma-Amaclari-Degerlendirme-Raporu_13_12_2019-WEB.pdf (accessed on 18.02.2021).

28. Van der Waldt, G. (2014). Public Administration teaching and interdisciplinarity: Considering the consequences, Teaching Public Administration, 32(2), 169-193, https://doi.org/10.1177/0144739414523285.

29. Van Dijk, H. G., \& Thornhill, C. (2011). An undergraduate curriculum analysis of Public Administration in selected higher education institutions, Administratio Publica, 19(1), 1-19, https://repository.up.ac.za/bitstream/handle/2263/19058/VanDijk_Undergraduate(2011).p df? sequence $=1$ (accessed on 27.05.2021).

30. Wessels, K. (2010). A core curriculum for the Master of Public Administration: Lessons from Australia and New Zealand, Administratio Publica, 18(3), 172-196, https://uir.unisa.ac.za/handle/10500/3952 (accessed on 20.06.2021).

31. Yıldız, M., Demircioğlu, M. A. \& Babaoğlu, C. (2011). Teaching public policy to undergraduate students: Issues, experiences, and lessons in Turkey, Journal of Public Affairs Education, 17(3), 343-365, https://doi.org/10.1080/15236803.2011.12001649.

32. Yıldız, M., Babaoğlu, C. \& Demircioğlu, M. A. (2016). E-government education in Turkish public administration graduate programs: Past, present and future, Journal of Public Affairs Education, 22(2), 287-302, https://doi.org/10.1080/15236803.2016.12002246.

33. Yıldız, M., Babaoğlu, C. \& Tugan, E. N. (2017). Türkiye'de kamu politikaları öğretiminde kurumsallaşma çabaları, SBF Dergisi, 72(3), 77-101, https://doi.org/10.1501/SBFder0000002463.

34. Yıldız, M. \& Babaoğlu, C. (2018). "Public Policy Education in Turkey: A Public Administration Perspective", in. Public Policy in Turkey (Ed. C. Bakır \& G. Ertan), Policy Press University of Bristol, Bristol, 271-288.

(c) 2021 by the authors. Licensee UAIC, Iasi, Romania. This article is an open access article distributed under the terms and conditions of the Creative Commons Attribution (CC BY-NC-ND) license (https://creativecommons.org/licenses/by-ncnd/4.0). 